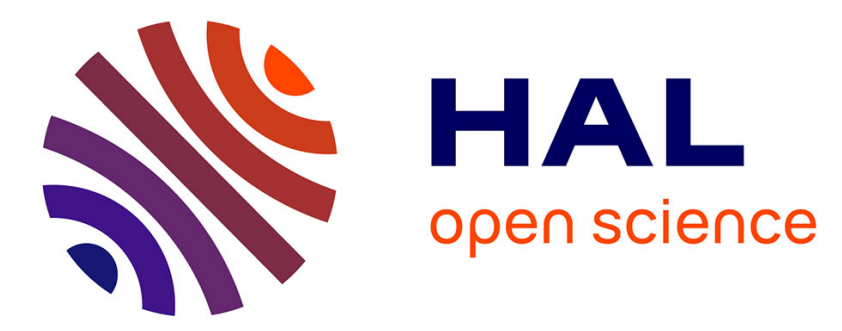

\title{
Further Observations Of A Decreasing Atmospheric Co2 Uptake Capacity In The Canada Basin (Arctic Ocean) Due To Sea Ice Loss
}

B. G. T. Else, R. J. Galley, B. Lansard, D. G. Barber, K. Brown, L. A. Miller, A. Mucci, T. N. Papakyriakou, J. E. Tremblay, S. Rysgaard

\section{To cite this version:}

B. G. T. Else, R. J. Galley, B. Lansard, D. G. Barber, K. Brown, et al.. Further Observations Of A Decreasing Atmospheric Co2 Uptake Capacity In The Canada Basin (Arctic Ocean) Due To Sea Ice Loss. Geophysical Research Letters, 2013, 40 (6), pp.1132-1137. 10.1002/grl.50268 . hal-00984553v2

\section{HAL Id: hal-00984553 \\ https://hal.science/hal-00984553v2}

Submitted on 25 Jun 2014

HAL is a multi-disciplinary open access archive for the deposit and dissemination of scientific research documents, whether they are published or not. The documents may come from teaching and research institutions in France or abroad, or from public or private research centers.
L'archive ouverte pluridisciplinaire HAL, est destinée au dépôt et à la diffusion de documents scientifiques de niveau recherche, publiés ou non, émanant des établissements d'enseignement et de recherche français ou étrangers, des laboratoires publics ou privés. 


\title{
Further observations of a decreasing atmospheric $\mathrm{CO}_{2}$ uptake capacity in the Canada Basin (Arctic Ocean) due to sea ice loss
}

\author{
Brent G.T. Else, ${ }^{1}$ R.J. Galley, ${ }^{1}$ B. Lansard, ${ }^{2}$ D.G. Barber, ${ }^{1}$ K. Brown, ${ }^{3}$ L.A. Miller, ${ }^{4}$ \\ A. Mucci, ${ }^{5}$ T.N. Papakyriakou, ${ }^{1}$ J.-É. Tremblay, ${ }^{6}$ and S. Rysgaard ${ }^{1}$ \\ Received 30 November 2012; revised 7 February 2013; accepted 18 February 2013; published 25 March 2013.
}

[1] Using data collected in 2009, we evaluated the potential for the southeastern Canada Basin (Arctic Ocean) to act as an atmospheric $\mathrm{CO}_{2}$ sink under the summertime ice-free conditions expected in the near future. Beneath a heavily decayed ice cover, we found surprisingly high $p \mathrm{CO}_{2 \mathrm{sw}}$ ( 290-320 $\mu \mathrm{atm})$, considering that surface water temperatures were low and the influence of ice melt was strong. A simple model simulating melt of the remaining ice and exposure of the surface water for 100 days revealed a weak capacity for atmospheric $\mathrm{CO}_{2}$ uptake (mean flux: $-2.4 \mathrm{mmol} \mathrm{m}^{-2} \mathrm{~d}^{-1}$ ), due largely to warming of the shallow mixed layer. Our results confirm a previous finding that the Canada Basin is not a significant sink of atmospheric $\mathrm{CO}_{2}$ under summertime ice-free conditions and that increased ventilation of the surface mixed layer due to sea ice loss is weakening the sink even further. Citation: Else, B. G. T., R. J. Galley, B. Lansard, D. G. Barber, K. Brown, L. A. Miller, A. Mucci, T. N. Papakyriakou, J.-É. Tremblay, and S. Rysgaard (2013), Further observations of a decreasing atmospheric $\mathrm{CO}_{2}$ uptake capacity in the Canada Basin (Arctic Ocean) due to sea ice loss, Geophys. Res. Lett., 40, 1132-1137, doi:10.1002/grl.50268.

\section{Introduction}

[2] One outcome of the recent retreat of Arctic sea ice is an increased potential for air-sea gas exchange. This phenomenon is particularly significant on the extensive Arctic shelves, where pronounced decreases in summer ice extent have progressively exposed the surface ocean over greater temporal and spatial scales [e.g., Arctic Monitoring and Assessment Programme, 2011]. Since the surface water of most Arctic shelf seas experience persistently low $\mathrm{CO}_{2}$ partial pressures $\left(p \mathrm{CO}_{2 \mathrm{sw}}\right)$ during the open-water season, the uptake of atmospheric $\mathrm{CO}_{2}$ in these areas is thought to have increased as a result of sea ice loss [e.g., Bates and Mathis, 2009].

All Supporting Information may be found in the online version of this article.

${ }^{1}$ CEOS, University of Manitoba, Winnipeg, Manitoba, Canada.

${ }^{2}$ LEGOS, Université Paul Sabatier, CNRS, Toulouse, France.

${ }^{3}$ Earth and Ocean Sciences, University of British Columbia, Vancouver, British Columbia, Canada.

${ }^{4}$ Institute of Ocean Sciences, Fisheries and Oceans Canada, Sidney, British Columbia, Canada.

${ }^{5}$ GEOTOP and Earth and Planetary Sciences, McGill University, Montréal, Québec, Canada.

${ }^{6}$ Départment de Biologie and Québec-Océan, Université Laval, Québec, Québec, Canada.

Corresponding author: Brent G.T. Else, University of Manitoba, Winnipeg, Manitoba, Canada. (b_else@umanitoba.ca)

(C2013. American Geophysical Union. All Rights Reserved. 0094-8276/13/10.1002/grl.50268
[3] In light of this increased $\mathrm{CO}_{2}$ uptake capacity on the shelves, there has been an emerging debate about the potential for the deep Arctic basins to absorb more $\mathrm{CO}_{2}$ as they become seasonally ice free [Bates et al., 2006; Cai et al., 2010; Jutterström and Anderson, 2010]. The southwest portion of the Canada Basin (adjacent to the Chukchi Sea) has already experienced a significant northward migration of the summer ice edge [Hutchings and Rigor, 2012], but Cai et al. [2010] showed the area to have a very limited capacity for atmospheric $\mathrm{CO}_{2}$ uptake. This low uptake capacity is thought to be the result of low biological productivity, surface warming, and a shallow mixed layer that can quickly equilibrate with the atmosphere. Based on their observations, Cai et al. [2010] concluded that the additional $\mathrm{CO}_{2}$ uptake afforded by continued loss of sea ice in the Canada Basin is probably minimal.

[4] This paper is an attempt to further test that hypothesis by examining the $\mathrm{CO}_{2}$ uptake capacity of the southeastern Canada Basin, adjacent to the Beaufort Sea (Figure 1). Previously, this region had retained relatively more sea ice in summer than the southwestern Canada Basin due to the southerly advection of ice within the Beaufort Gyre [Hutchings and Rigor, 2012]. However, in 2012, a dramatic northward retreat of the ice edge occurred (NSIDC Arctic Sea Ice News and Analysis, 2012, http://nsidc.org/ arcticseaicenews/), exposing surface waters in the region for an extended period of time. In light of this development, the objectives of this study are to assess the $\mathrm{CO}_{2}$ uptake potential in this region of recent ice loss and to compare our results with those obtained by Cai et al. [2010] to further investigate the atmospheric $\mathrm{CO}_{2}$ uptake capacity of the Canada Basin.

\section{Methods}

[5] From 27 August to 12 September 2009, a multidisciplinary cruise was conducted in the southeastern Canada Basin onboard the CCGS Amundsen, as a joint International Polar Year effort between ArcticNet and GEOTRACES. The ship traveled north from the Mackenzie River delta $\left(69.5^{\circ} \mathrm{N}\right)$ along $\sim 139^{\circ} \mathrm{W}$, eventually reaching $75.3^{\circ} \mathrm{N}$ before returning along $\sim 136^{\circ} \mathrm{W}$ (Figure 1), stopping at several locations along the route to conduct sampling using a conductivity-temperature-depth (CTD)/rosette system.

[6] An underway $p \mathrm{CO}_{2 \mathrm{sw}}$ system (General Oceanics model 8050 [Pierrot et al., 2009]) was operated throughout the cruise, sampling water from a high-volume inlet located near the bow of the ship at a nominal depth of $5 \mathrm{~m}$. The system calibration was monitored with twice-daily checks against three certified gas standards $\left(\mathrm{CO}_{2}\right.$ concentrations of $0.0,359.6$, and $455.7 \mathrm{ppm})$. Although the system was located close to the inlet, a temperature gauge in the equilibrator recorded an increase of $1.0 \pm 0.7^{\circ} \mathrm{C}$ relative to 

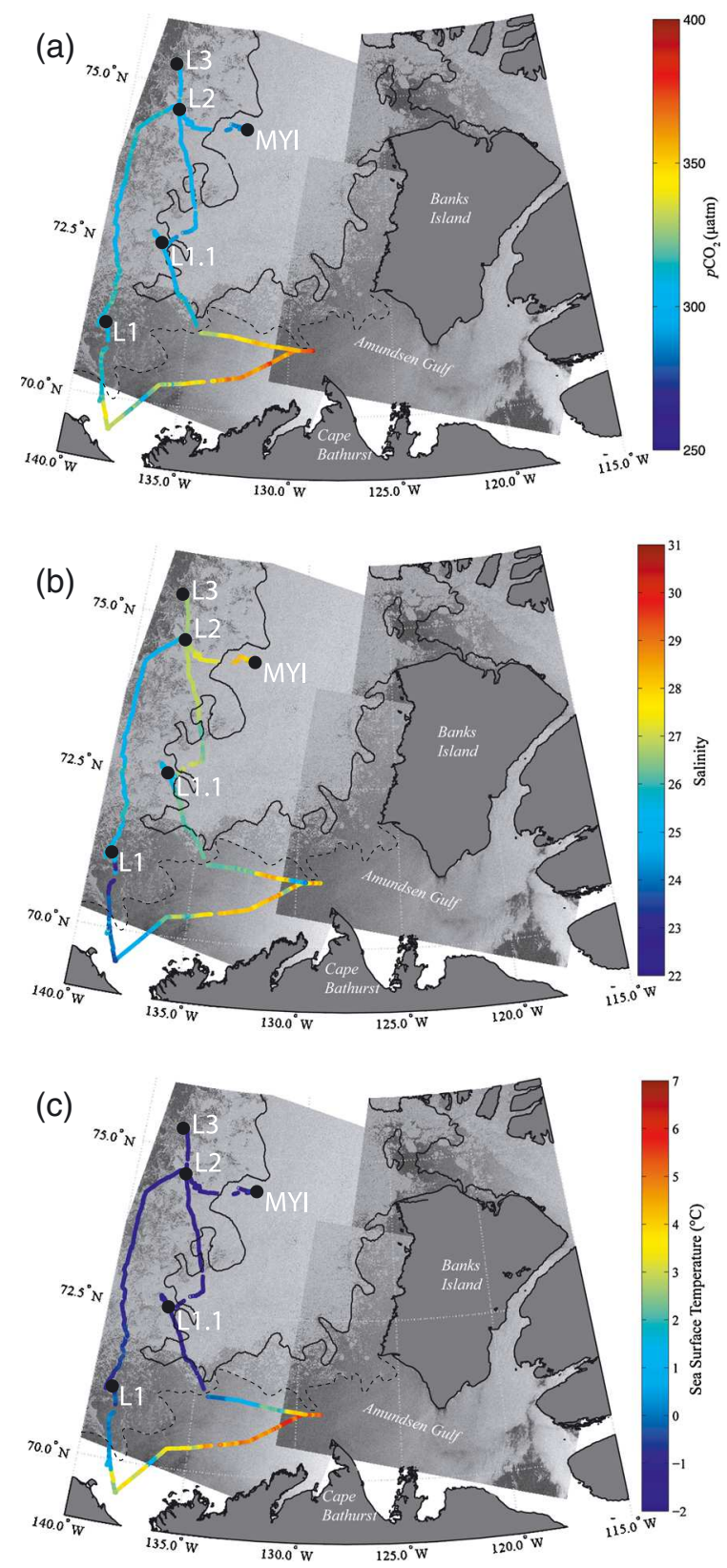

Figure 1. Underway surface water measurements: (a) observed $\mathrm{pCO}_{2}$, (b) salinity, and (c) sea surface temperature, overlain on a composite of RADARSAT-1 images collected during the study period. The sampling stations (including a multi-year ice sampling station labeled "MYI") are indicated. The black line indicates the approximate location of the multiyear ice tongue based on Canadian Ice Service charts, and the dashed line delineates the location of lower concentration ice composed of a mixture of first-year and multi-year floes.

on-station measurements made by the ship's CTD. This mean on-station offset was used to correct all $p \mathrm{CO}_{2 \mathrm{sw}}$ measurements for thermodynamic effects, eliminating the warming bias but introducing an uncertainty of $\pm 3 \%$ to the $p \mathrm{CO}_{2 \text { sw }}$ measurements. The underway system also housed a flowthrough CTD (Idronaut model Ocean Seven 315) which provided continuous salinity measurements.

[7] At four of the stations visited on the cruise track (L1, L1.1, L2, and L3, see Figure 1), a suite of biogeochemical measurements was conducted on seawater samples collected by $12 \mathrm{~L}$ Niskin bottles fixed on the rosette. To characterize the carbonate system, total alkalinity (TA) was measured by open-cell potentiometric titration (Radiometer Analytical ${ }^{\circledR}$ TIM865 TitraLab), and $\mathrm{pH}$ was measured by a UV-VIS diode array spectrophotometer (Agilent-HP ${ }^{\circledR}$ 8453) using phenol red and $m$-cresol purple indicators [Mucci et al., 2010]. The $\mathrm{pH}$ samples were handled carefully to avoid equilibration with the atmosphere, and dissolved inorganic carbon (DIC) and $p \mathrm{CO}_{2 \mathrm{sw}}$ values derived from these measurements have been shown to be consistent with direct measurements [Lansard et al., 2012; Mucci et al., 2010]. Hence, we calculated DIC and $p \mathrm{CO}_{2}$ from TA/pH measurements using CO2SYS [Lewis and Wallace, 1998] and the carbonic acid dissociation constants of Mehrbach et al. [1973] as refit by Dickson and Millero [1987]. Concentrations of macronutrients (nitrate + nitrite, nitrite, phosphate, ammonium, and silicate) were determined from fresh samples using standard colorimetric methods and an Autoanalyzer 3 (see Tremblay et al. [2008] for details). Seawater samples were also taken for stable oxygen isotope analysis $\left(\delta^{18} \mathrm{O}\right)$, conducted at the Stable Isotope Geochemistry Laboratory (GEOTOP). The $\delta^{18} \mathrm{O}$ data were used in an optimum multiparameter (OMP) algorithm that also utilized salinity and TA to quantify the fractional contributions of source water types to the surface water mass at the sample sites. A description of the OMP and its full results will be published in a forthcoming paper, but the relevant methodology, including the water type end-members and their characteristics, is available in Lansard et al. [2012]. For all CTD casts (including on-station casts where biogeochemical sampling was not conducted), surface mixed layer depth was calculated as the depth where potential density increased by $0.1 \mathrm{~kg} \mathrm{~m}^{-3}$ relative to the shallowest measurement [Toole et al., 2010].

\section{Observations}

[8] In late summer of 2009, the shelf seas in our study area were completely exposed to the atmosphere (Figure 1), while the deep basin was covered by a heterogeneous sea ice cover that extended to $150^{\circ} \mathrm{W}$ [Barber et al., 2009]. As discussed in Barber et al. [2009] and Galley et al. [2013], ice in the area between $\sim 140^{\circ} \mathrm{W}$ and $\sim 135^{\circ} \mathrm{W}$ was mostly heavily decayed first-year sea ice interspersed with multi-year floes, and the mean thickness observed on helicopter surveys ranged from 0.5 to $1.1 \mathrm{~m}$. To the east of $135^{\circ} \mathrm{W}$ was a tongue of multi-year ice that was much thicker (mean $\sim 1.8 \mathrm{~m}$ ), but still heavily decayed (Figure 1).

[9] As Figure 1a shows, $p \mathrm{CO}_{2 \mathrm{sw}}$ under both of these ice types was considerably lower (mean and standard deviation: $305 \pm 10 \mu \mathrm{atm})$ than on the exposed shelf, where $p \mathrm{CO}_{2 \mathrm{sw}}$ ranged from 300 to $370 \mu \mathrm{atm}$. Spatial variability under the ice cover was muted, although $p \mathrm{CO}_{2 \text { sw }}$ was slightly higher $(311 \pm 5 \mu \mathrm{atm})$ on the western transect than on the eastern transect $(301 \pm 9 \mu \mathrm{atm})$ and was lowest under the multi-year ice $(289 \pm 5 \mu \mathrm{atm})$. Lower salinity (mean 25.3 vs. 26.2, Figure 1b) and higher sea surface temperature (SST) (mean $-1.0^{\circ} \mathrm{C}$ vs. $-1.3^{\circ} \mathrm{C}$, Figure $1 \mathrm{c}$ ) were observed on the west side of the study area, and the highest salinities (mean 28.2) were observed under the multi-year ice.

[10] A summary of the conditions observed at each station is shown in Table 1. The OMP analysis revealed that much of the variability in the water properties (salinity, SST, and chemical composition) between stations can be explained by varying contributions of sea ice melt. At stations L1 
ELSE ET AL.: SEA ICE LOSS AND ATMOSPHERIC $\mathrm{CO}_{2}$ UPTAKE

Table 1. Summary of Surface Water Conditions (3-4 m Depth) Observed at the Four Sampling Stations ${ }^{\mathrm{a}}$

\begin{tabular}{|c|c|c|c|c|}
\hline & \multicolumn{4}{|c|}{ Station } \\
\hline & L1 & L1.1 & L2 & L3 \\
\hline Date & 31 Aug & 09 Sept & $04 \mathrm{Sept}$ & 07 Sept \\
\hline Depth (m) & 1914 & 2533 & 3000 & 3000 \\
\hline $\operatorname{SST}\left({ }^{\circ} \mathrm{C}\right)$ & -1.039 & -1.34 & -1.401 & -1.388 \\
\hline Salinity & 25.536 & 25.267 & 26.736 & 26.454 \\
\hline $\mathrm{pH}$ & 8.0562 & 8.0804 & 8.0966 & 8.0906 \\
\hline $\mathrm{TA}\left(\mu \mathrm{mol} \mathrm{L}{ }^{-1}\right)$ & 1842.3 & 1850.0 & 1951.9 & 1944.7 \\
\hline $\operatorname{DIC}\left(\mu \mathrm{mol} \mathrm{L}^{-1}\right)$ & 1772.3 & 1777.0 & 1867.0 & 1862.0 \\
\hline Revelle factor & 17.9 & 17.8 & 17.2 & 17.3 \\
\hline$p \mathrm{CO}_{2}{ }^{\mathrm{b}}(\mu \mathrm{atm})$ & 316 & 301 & 305 & 301 \\
\hline$p \mathrm{CO}_{2}{ }^{\mathrm{c}}(\mu \mathrm{atm})$ & 309 & 300 & 304 & 300 \\
\hline Nitrate $\left(\mu \mathrm{mol} \mathrm{L}^{-1}\right)$ & not collected & 0 & 0.15 & 0.06 \\
\hline Phosphate $\left(\mu \mathrm{mol} \mathrm{L}^{-1}\right)$ & not collected & 2 & 1.5 & 2.3 \\
\hline Silicate $\left(\mu \mathrm{mol} \mathrm{L}^{-1}\right)$ & not collected & 0.5 & 0.55 & 0.51 \\
\hline Ammonium $\left(\mu \mathrm{mol} \mathrm{L}^{-1}\right)$ & not collected & 0.04 & 0.01 & 0.01 \\
\hline MW (\%) & 7 & 9 & 8 & 9 \\
\hline SIM (\%) & 17 & 16 & 11 & 12 \\
\hline PML (\%) & 75 & 75 & 81 & 80 \\
\hline Ice thickness (m) & 1.09 & 0.86 & 0.65 & 0.49 \\
\hline Ice concentration (\%) & 60 & 80 & 90 & 90 \\
\hline
\end{tabular}

${ }^{\mathrm{a}}$ The results of the optimum multiparameter analysis are also shown as the mass percentage of each water type $(\mathrm{MW}=\mathrm{Mackenzie}$ River water, $\mathrm{SIM}=$ sea ice melt water, $\mathrm{PML}=$ polar mixed layer water) that makes up the surface water at the four stations. Ice thicknesses are from Galley et al. [2013], and ice concentrations are from Canadian Ice Service charts.

${ }^{\mathrm{b}} \mathrm{Calculated}$ from $\mathrm{TA} / \mathrm{pH}$ using $\mathrm{CO} 2 \mathrm{SYS}$.

${ }^{c}$ From underway $p \mathrm{CO} 2$ system.

and L1.1, sea ice melt water composed $16 \%-17 \%$ of the mass of the under-ice water while only accounting for $11 \%$ of the mass at stations L2 and L3. This influence of ice melt was reflected in lower salinity, lower DIC and TA, and higher SST at the southern stations (Table 1) and is probably also responsible for much of the heterogeneity apparent in the underway system data (Figure 1).

[11] From the vertical profile data (see supplemental Figure S1 in the auxiliary material), we generally observed a shallow mixed layer at the stations (mean depth of $15.3 \mathrm{~m}$ with a range of 10 to $23 \mathrm{~m}$ ), delimited by a sharp pycnocline. DIC, TA, and $p \mathrm{CO}_{2}$ increased rapidly with depth below the mixed layer (while $\mathrm{pH}$ decreased), whereas $p \mathrm{CO}_{2}$ reached a maximum around $150 \mathrm{~m}$ depth (in the upper halocline layer [e.g., Lansard et al., 2012]). Macronutrient concentrations also peaked in that layer, but more relevant to the present study was a complete absence of nitrate, with small residuals of phosphate, silicate, and ammonium in the mixed layer (see also Table 1). Data from a fluorometer attached to the CTD showed a subsurface chlorophyll maximum centered around $60 \mathrm{~m}$, well below the mixed layer.

\section{4. $\mathrm{CO}_{2}$ Uptake Potential}

[12] To investigate atmospheric $\mathrm{CO}_{2}$ uptake potential at each of the sampling stations, we performed a simple modeling exercise. At each station, the model calculates an initial surface DIC, TA, and $p \mathrm{CO}_{2 \mathrm{sw}}$, assuming that the remaining ice cover melts completely (ice thicknesses for each station are shown in Table 1, and we use a sea ice melt end-member whose properties are as follows: $\mathrm{DIC}=330$ $\mu \mathrm{mol} \mathrm{kg}{ }^{-1}, \mathrm{TA}=415 \mu \mathrm{mol} \mathrm{kg}{ }^{-1}$, salinity $=4.7$ to average values from Rysgaard et al. [2009] and Miller et al. [2011], as reported by Lansard et al. [2012]). Since fixed inorganic nitrogen was depleted in the surface mixed layer, we assume that further biological $p \mathrm{CO}_{2}$ reduction would be negligible. The model is then run at $6 \mathrm{~h}$ intervals over a simulated 100 day open-water season, assuming that the sea surface warms at a rate of $0.13^{\circ} \mathrm{Cd}^{-1}$ for 50 days and then cools at the inverse rate. This warming rate produces a maximum SST of $5^{\circ} \mathrm{C}$, which is similar to satellite observations in the area during the 2012 ice retreat event (NSIDC Arctic Sea Ice News and Analysis, 2012, http://nsidc.org/ arcticseaicenews/), and the symmetrical length of the warming and cooling periods is similar to observations we made in the southeastern Beaufort Sea the previous summer [Else et al., 2013]. At each $6 \mathrm{~h}$ interval, air-sea gas exchange is calculated as the product of the air-sea $p \mathrm{CO}_{2}$ gradient (using $387 \mu \mathrm{atm}$ as the atmospheric value), the gas transfer velocity (a function of wind speed, which we set at a mean value of $4.6 \mathrm{~m} \mathrm{~s}^{-1}$ based on measurements at nearby landbased weather stations), and the gas solubility (a function of salinity and SST). Gas transfer velocity is calculated using the quadratic expression appropriate for long-term mean winds described by Wanninkhof et al. [2002]. At each time-step of the model, the mixed layer DIC and $p \mathrm{CO}_{2 \mathrm{sw}}$ arising from gas exchange are computed using a Matlab version of CO2SYS, and the results are passed on to the next iteration of the model.

[13] We also performed several sensitivity tests of the model, using the mean surface conditions (and the above warming rate and wind velocity) for all stations as a baseline and then perturbing parameters that either had high uncertainty or were expected to have a strong influence on the calculated $\mathrm{CO}_{2}$ flux. For these tests, the warming/cooling rate was varied between $0.09^{\circ} \mathrm{C}$ and $0.17^{\circ} \mathrm{C} \mathrm{d}^{-1}$ (the upper rate reflecting observations of Else et al. [2012a] in nearby Amundsen Gulf in 2008, and the lower rate reflecting observations of Cai et al. [2010]), surface mixed layer depth was varied between 10 and $23 \mathrm{~m}$ (reflecting the range of mixed layer depths that we encountered during this study), wind velocity was varied between 4.0 and $5.2 \mathrm{~m} \mathrm{~s}^{-1}$ 
(reflecting variability around the mean wind velocity observed at nearby weather stations), and the TA:DIC ratio in sea ice melt water was varied between 1.1 and 1.5 (reflecting observed variability in ice melt chemistry [e.g., Rysgaard et al., 2009]).

[14] Results of the modeling exercise (Figure 2) support the hypothesis that the surface waters in our study region cannot absorb significant amounts of atmospheric $\mathrm{CO}_{2}$ during an extended ice-free event. At the four stations, the mean $\mathrm{CO}_{2}$ exchange rate over the 100 day model run ranged between -2.3 and $-2.6 \mathrm{mmol} \mathrm{m}^{-2} \mathrm{~d}^{-1}$, with an overall mean of $-2.4 \mathrm{mmolm}^{-2} \mathrm{~d}^{-1}$. This mean value is $\sim 60 \%$ lower than the mean uptake rate estimated by Cai et al. [2010] over a similar 100 day period in the southwestern Canada Basin the previous year and 95\% lower than estimates made by Bates et al. [2006] based on extrapolations of measurements made on the adjacent shelves.

[15] Perhaps the most interesting feature of our model results is the oversaturation that occurs after less than 1 month, when sea surface warming causes $p \mathrm{CO}_{2 \text { sw }}$ to exceed the atmospheric value by about $30 \mu$ atm (Figure $2 \mathrm{a}$ ). We observed a similar phenomenon in Amundsen Gulf in 2008 [Else et al., 2012a, 2013], although the degree of
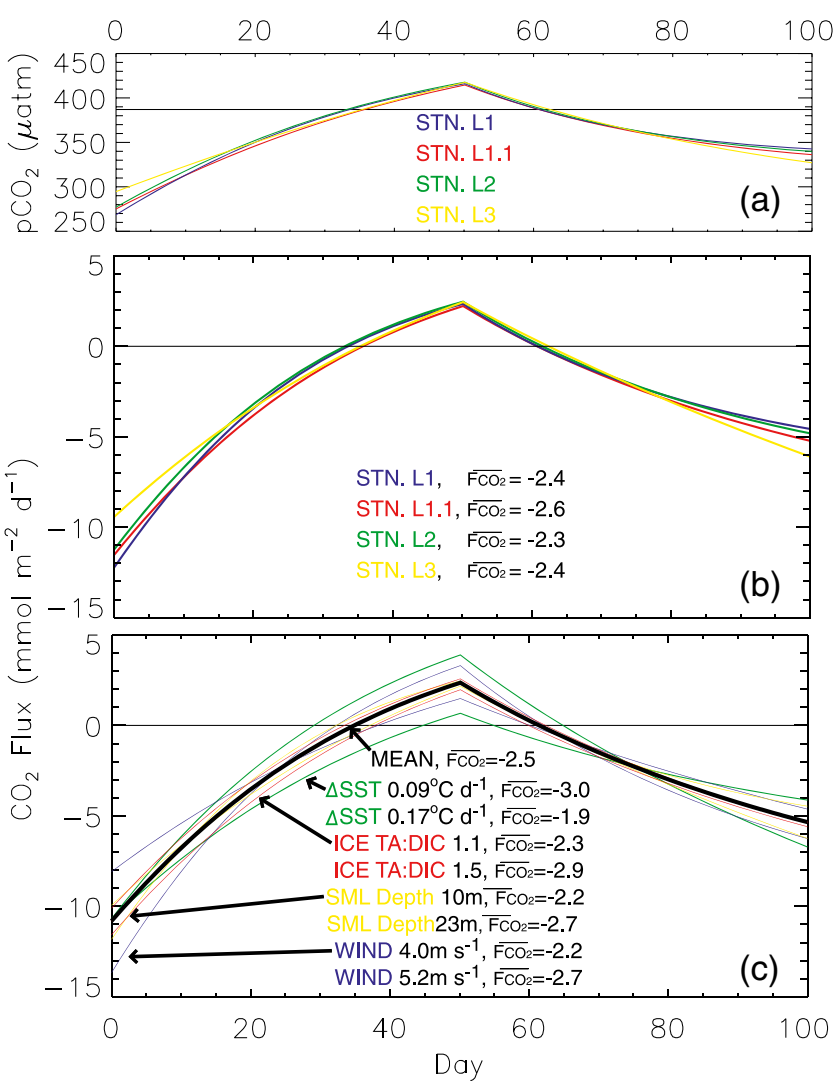

Figure 2. Results from the air-sea gas exchange model: (a) $p \mathrm{CO}_{2 \mathrm{sw}}$ evolution during the model runs for the four sampling stations, with the horizontal line denoting atmospheric $p \mathrm{CO}_{2}$; (b) air-sea $\mathrm{CO}_{2}$ flux evolution during the model runs for the four sampling station, with mean $\mathrm{CO}_{2}$ flux for the 100 day period noted for each station as $\overline{F_{\mathrm{CO}_{2}}}$; (c) air-sea $\mathrm{CO}_{2}$ flux evolution during the sensitivity runs, with $\mathrm{F}_{\mathrm{CO}_{2}}^{-}$noted for each run. oversaturation was not as significant $(\sim 10 \mu \mathrm{atm})$. The modeled oversaturation occurs over a period of about 27 days (Figure 2b), limiting the total amount of $\mathrm{CO}_{2}$ that the surface waters can absorb. Consequently, little DIC is actually added to the surface water over the 100 day period; for the four stations that we modeled, DIC only increased by an average of $18 \mu \mathrm{mol} \mathrm{kg}^{-1}$ by the end of the model run. This phenomenon occurs because some of the DIC added during the initial uptake period is subsequently released during the outgassing period. The uptake period that follows as the surface water cools toward its freezing point is then insufficient to allow $p \mathrm{CO}_{2 \mathrm{sw}}$ to reach equilibrium, and the result is undersaturation at the end of the open-water season - a condition observed across much of the Beaufort Shelf in 2008 [Else et al., 2012a, 2012b].

[16] In their analysis, Cai et al. [2010] emphasized the rapid equilibration of the shallow surface mixed layer as a critical factor inhibiting significant uptake of atmospheric $\mathrm{CO}_{2}$. Our results highlight that the rapid warming that occurs in this layer when the ice is removed is another critical component of the system. The sensitivity tests show that over the range of conditions expected for our study area (Figure 2c), the potential for atmospheric $\mathrm{CO}_{2}$ uptake is most sensitive to surface warming. Furthermore, generating a $p \mathrm{CO}_{2 \mathrm{sw}}$ oversaturation requires a relatively small increase in SST; modeled $p \mathrm{CO}_{2 \mathrm{sw}}$ at all stations exceeded the atmospheric value when SST reached approximately $3^{\circ} \mathrm{C}$. Overall, our sensitivity analysis confirmed that weak uptake is expected in this area following sea ice retreat no matter how the model is perturbed, and it consistently predicts an even smaller uptake than reported in 2008 by Cai et al. [2010].

\section{Discussion}

[17] The observation of a lower uptake capacity in 2009 relative to 2008 is potentially important, provided it is not an artifact arising from differences between our model and the model of Cai et al. [2010]. This does not seem to be the case as $p \mathrm{CO}_{2 \mathrm{sw}}$ at the initial state of our model runs (mean $\sim 280 \mu \mathrm{atm}$ ) was considerably higher than $p \mathrm{CO}_{2 \mathrm{sw}}$ at the initial state used by Cai et al. [2010] ( 225 $\mu \mathrm{atm})$, despite both studies using essentially the same SST and sea ice melt end-members to define those states. Thus, the 2009 data will produce a lower uptake potential no matter which model is used, and we can conclude that not all of the differences between the two studies can be attributed to model implementation.

[18] A second potential cause of the difference is variability in surface water compositions between the two study regions [e.g., Macdonald et al., 2002]. Most notably, the southwestern Canada Basin that Cai et al. [2010] studied is directly influenced by outflow from the Chukchi Shelf, whose surface waters typically have a strong capacity to absorb atmospheric $\mathrm{CO}_{2}$ [Bates et al., 2006]. In the southeastern Canada Basin, surface waters on the adjacent shelves have a significantly lower capacity to absorb atmospheric $\mathrm{CO}_{2}$ [Shadwick et al., 2011]. Thus, varying contributions of shelf-basin exchange could account for the lower uptake capacity in our region. However, the source water type analysis (Table 1) shows that shelf water did not make up a significant fraction of the surface mixed layer in our study region in 2009, indicating that we were measuring a signal consistent with deep basin waters. Given the connection between the southeastern Canada Basin (this work) and the southwestern Canada Basin [Cai et al., 
2010] via the Beaufort Gyre [e.g., Hutchings and Rigor, 2012; Galley et al., 2013], it is plausible to infer that we were both measuring essentially the same water mass.

[19] This leaves increased ventilation of the surface mixed layer due to sea ice loss as the most likely cause of the observed decline in $\mathrm{CO}_{2}$ uptake capacity. In the past, DICundersaturated surface water that exited the Chukchi Shelf was precluded from further air-sea gas exchange by the perennial sea ice cover [Anderson et al., 2010], and hence, surface water in the Canada Basin retained some $\mathrm{CO}_{2}$ uptake potential. However, Cai et al. [2010] showed that extended open-water seasons can significantly deplete this uptake capacity. We can use our results to illustrate this phenomenon by considering that Cai et al. [2010] predicted a $p \mathrm{CO}_{2 \mathrm{sw}}$ value of around $370 \mu \mathrm{atm}$ at $4^{\circ} \mathrm{C}$ by the end of the 2008 summer, which if cooled to $-1.4^{\circ} \mathrm{C}$ produces a $p \mathrm{CO}_{2 \mathrm{sw}}$ of $298 \mu \mathrm{atm}$. If winter modifications of $p \mathrm{CO}_{2 \mathrm{sw}}$ are minimal, the initial conditions of the following summer should in some way reflect this value. This is precisely what the initial state of our 2009 model runs show $\left(p \mathrm{CO}_{2 \mathrm{sw}} \sim 280 \mu \mathrm{atm}\right)$, which helps confirm the hypothesis that the $\mathrm{CO}_{2}$ sink in this region is unsustainable during long periods of open water like the summer of 2008.

[20] How this situation evolves in the Canada Basin in the future is uncertain. Longer open-water seasons will alleviate light limitation on primary production [Arrigo et al., 2008], potentially enhancing biological reduction of $p \mathrm{CO}_{2 \mathrm{sw}}$. However, the nutrient limitation that seems to be ubiquitous across the Canada Basin (Figure S1 [Cai et al., 2010; Jutterström and Anderson, 2010]) will significantly constrain this effect. In the future, nutrients may be replenished by enhanced upwelling permitted by more extensive open water [e.g., Tremblay et al., 2011], but strong upwelling may episodically bring the carbon-rich upper halocline layer into contact with the atmosphere-a phenomenon which can briefly change weak $\mathrm{CO}_{2}$ sink areas into $\mathrm{CO}_{2}$ sources [Else et al., 2012a, 2012b; Lansard et al. 2012; Mathis et al., 2012; Mucci et al., 2010]. Conversely, changing sea ice processes have the potential to push the system toward stronger uptake; the sea ice pump (which describes the partitioning of DIC-enriched brine at depth and TA-enriched melt water at the surface [e.g., Rysgaard et al., 2009]) may become more effective with a transition from perennial to annual sea ice, and uptake during initial ice formation [Anderson et al., 2004; Else et al., 2011] may become more widespread as the area undergoing freeze-thaw cycles expands. Finally, a significant freshening of the Canada Basin has been observed in the last decade [McPhee et al., 2009; Morison et al., 2012; Yamamoto-Kawai et al., 2009a], increasing surface stratification and modifying carbonate chemistry [Yamamoto-Kawai et al., 2009b]. Ultimately, the net effect of these climate change impacts on $\mathrm{CO}_{2}$ uptake in the future remains to be seen, but for now, all evidence points to very limited atmospheric $\mathrm{CO}_{2}$ uptake as the waters of the Canada Basin become increasingly exposed to the atmosphere.

[21] Acknowledgments. Authors of this paper are members of ArcticNet (funded in part by NCE, NSERC, CIHR, and SSHRC) and the Arctic Science Partnership. Additional support was provided through the Canada Excellence Research Chair in Arctic Geomicrobiology and Climate Change, and from the Centre for Earth Observation Science at the University of Manitoba. Many thanks are owed to the captains, crew, and research technicians onboard the CCGS Amundsen.

\section{References}

Arctic Monitoring and Assessment Programme, 2011. Snow, water, ice and permafrost in the Arctic (SWIPA): Climate change and the cryosphere. Arctic Monitoring and Assessment Programme (AMAP), Oslo, Norway.

Arrigo, K. R., G. van Dijken, and S. Pabi (2008), Impact of a shrinking Arctic ice cover on marine primary production, Geophys. Res. Lett., 35, L19603, doi:10.1029/2008GL035028.

Anderson, L. G., E. Falck, E. P. Jones, S. Jutterström, and J. H. Swift (2004), Enhanced uptake of atmospheric $\mathrm{CO}_{2}$ during freezing of seawater: A field study in Storfjorden, Svalbard, J. Geophys. Res., 109, C06004, doi:10.1029/2003JC002120.

Anderson, L. G., T. Tanhua, G. Björk, S. Hjalmarsson, E. P. Jones, S. Jutterström, B. Rudels, J. H. Swift, and I. Wåhlström (2010), Arctic ocean shelf-basin interaction: An active continental shelf $\mathrm{CO}_{2}$ pump and its impact on the degree of calcium carbonate solubility, Deep-Sea Res. I, 57, 869-879, doi:10.1016/j.dsr.2010.03.012.

Barber, D. G., R. Galley, M. G. Asplin, R. De Abreu, K.-A. Warner, M. Pućko, M. Gupta, S. Prinsenberg, and S. Julien (2009), Perennial pack ice in the Beaufort Sea was not as it appeared in the summer of 2009, Geophys. Res. Lett., 36, L24501, doi:10.1029/2009GL041434.

Bates, N. R., S. B. Moran, D. A. Hansell, and J. T. Mathis (2006), An increasing $\mathrm{CO}_{2}$ sink in the Arctic Ocean due to sea-ice loss, Geophys. Res. Lett., 33, L23609, doi:10.1029/2006GL027028.

Bates, N. R. and J. T. Mathis (2009), The Arctic Ocean marine carbon cycle: Evaluation of air-sea $\mathrm{CO}_{2}$ exchanges, ocean acidification impacts and potential feedbacks, Biogeosciences, 6(11), 2433-2459, doi:10.5194/ bg-6-2433-2009.

Cai, W., et al. (2010), Decrease in the $\mathrm{CO}_{2}$ uptake capacity in an ice-free Arctic Ocean basin, Science, 329(5991), 556-559, doi:10.1126/ science. 1189338

Dickson, A. G. and F. J. Millero (1987), A comparison of the equilibrium constants for the dissociation of carbonic acid in seawater media, DeepSea Res. 34, 1733-1743.

Else, B. G. T., T. N. Papakyriakou, R. J. Galley, W. M. Drennan, L. A. Miller, and $\mathrm{H}$. Thomas (2011), Wintertime $\mathrm{CO}_{2}$ fluxes in an Arctic polynya using eddy covariance: Evidence for enhanced air-sea gas transfer during ice formation, J. Geophys. Res., 116, C00G03, doi:10.1029/2010JC006760.

Else, B. G. T., T. N. Papakyriakou, R. J. Galley, A. Mucci, M. Gosselin, L. A. Miller, E. H. Shadwick, and H. Thomas (2012a), Annual cycles of $p \mathrm{CO}_{2 \mathrm{sw}}$ in the southeastern Beaufort Sea: New understandings of air-sea $\mathrm{CO}_{2}$ exchange in Arctic polynya regions, J. Geophys. Res., 117, C00G13, doi:10.1029/2011JC007346.

Else, B. G. T., R. J. Galley, T. N. Papakyriakou, L. A. Miller, A. Mucci, and D. Barber (2012b), Sea surface $p \mathrm{CO}_{2}$ cycles and $\mathrm{CO}_{2}$ fluxes at landfast sea ice edges in Amundsen Gulf, Canada, J. Geophys. Res., 117, C09010, doi:10.1029/2012JC007901.

Else, B. G. T., Papakyriakou, T. N., Asplin, M. G., Barber, D. G., Gallery, R. J., Miller, L. A., and A. Mucci (2013), Annual cycle of air-sea $\mathrm{CO}_{2}$ exchange in an Arctic polynya region. Global Biogeochemical Cycles, in press.

Galley, R. J., B. G. T. Else, S. J. Prinsenberg, and D. G. Barber (2013), Sea ice concentration, extent, age, motion and thickness in regions of proposed offshore oil and gas development near the Mackenzie Delta Canadian Beaufort Sea, Arctic, 66(1).

Hutchings, J. K., and I. G. Rigor (2012), Role of ice dynamics in anomalous ice conditions in the Beaufort Sea during 2006 and 2007, J. Geophys. Res., 117, C00E04, doi:10.1029/2011JC007182.

Jutterström, S. and L. G. Anderson (2010), Uptake of $\mathrm{CO}_{2}$ by the Arctic Ocean in a changing climate, Mar. Chem., 122, 96-104. doi:10.1016/j. marchem.2010.07.002.

Lansard, B., A. Mucci, L. A. Miller, R. W. MacDonald, and Y. Gratton (2012), Seasonal variability of water mass distribution in the southeastern Beaufort Sea determined by total alkalinity and $\delta^{18} \mathrm{O}$, J. Geophys. Res., 117, C03033, doi:10.1029/2011JC007299.

Lewis, E. and D. W. R. Wallace (1998), Program developed for CO2 system calculations, Rep. ORNL/CDIAC-105, Carbon Dioxide Inf. Anal. Cent., Oak Ridge Natl. Lab., U.S. Dep. Of Energy, Oak Ridge, Tenn. [Available at http://cdiac.esd.ornl.gov/oceans/co2rprt.html].

Macdonald, R. W., F. A. McLaughlin, and E. C. Carmack (2002), Fresh water and its sources during the SHEBA drift in the Canada Basin of the Arctic Ocean. Deep-Sea Res. I, 49, 1769-1785, doi:10.1029/JC094iC12p18057.

Mathis, J. T., et al. (2012), Storm-induced upwelling of high $p \mathrm{CO}_{2}$ waters onto the continental shelf of the western Arctic Ocean and implications for carbonate mineral saturation states, Geophys. Res. Lett., 39, L07606, doi:10.1029/2012GL051574.

McPhee, M. G., A. Proshutinsky, J. H. Morison, M. Steele, and M. B. Alkire (2009), Rapid change in freshwater content of the Arctic Ocean, Geophys. Res. Lett., 36, L10602, doi:10.1029/2009GL037525.

Mehrbach, C., C. H. Culberson, J. E. Hawley, and R. N. Pytkowicz (1973), Measurement of the apparent dissociation constants of carbonic acid in seawater at atmospheric pressure. Limnol. Oceanogr. 18(6), 897-907. 


\section{ELSE ET AL.: SEA ICE LOSS AND ATMOSPHERIC $\mathrm{CO}_{2}$ UPTAKE}

Miller, L. A., T. N. Papakyriakou, R. E. Collins, J. W. Deming, J. K. Ehn, R. W. Macdonald, A. Mucci, O. Owens, M. Raudsepp, and N. Sutherland (2011), Carbon dynamics in sea ice: A winter flux time series, J. Geophys. Res., 116, C02028, doi:10.1029/2009JC006058.

Morison, J., R. Kowk, C. Peralta-Ferriz, M. Alkire, I. Rigor, R. Anderson and M. Steele (2012), Changing Arctic Ocean freshwater pathways, Nature, 481, doi:10.1038/nature10705.

Mucci, A., B. Lansard, L. A. Miller, and T. N. Papakyriakou (2010), $\mathrm{CO}_{2}$ fluxes across the air-sea interface in the southeastern Beaufort Sea: Icefree period, J. Geophys. Res., 115, C04003, doi:10.1029/2009JC005330.

Pierrot D., C. Neill, K. Sullivan, R. Castle, R. Wanninkhof, H. Lüger, T. Johannessen, A. Olsen, R. A. Feeley, and C. E. Cosca (2009). Recommendations for autonomous underway $\mathrm{pCO}_{2}$ measuring systems and data-reduction routines. Deep-Sea Res. II, 56, 512-522, doi:10.1016/j. dsr2.2008.12.005

Rysgaard, S., J. Bendtsen, L. T. Pedersen, H. Ramløv, and R. N. Glud (2009), Increased $\mathrm{CO}_{2}$ uptake due to sea ice growth and decay in the Nordic Seas. J. Geophys. Res., 114, C09011, doi:10.1029/2008JC005088.

Shadwick, E. H., et al. (2011), Seasonal variability of the inorganic carbon system in the Amundsen Gulf region of the southeastern Beaufort Sea. Limnol. Oceanogr., 56(1), 303-322, doi:10.4319/1o.2011.56.1.0303.

Toole, J. M., M.-L. Timmermans, D. K. Perovich, R. A. Krishfield, A. Proshutinsky, and J. A. Richter-Menge (2010), Influences of the ocean surface mixed layer and thermohaline stratification on Arctic Sea ice in the central Canada Basin. J. Geophys. Res., 115, C10018, doi:10.1029/ 2009JC005660.

Tremblay, J.-É., K. Simpson, J. Martin, L. Miller, Y. Gratton, D. Barber, and N. M. Price (2008), Vertical stability and the annual dynamics of nutrients and chlorophyll fluorescence in the coastal, southeast Beaufort Sea. J. Geophys. Res., 113, C07S90, doi:10.1029/ 2007JC004547.

Tremblay, J.-É., et al. (2011), Climate forcing multiplies biological productivity in the coastal Arctic Ocean, Geophys. Res. Lett., 38, L18604, doi:10.1029/2011GL048825.

Wanninkhof, R., Doney, S. C., Takahashi, T., and W. R. McGillis (2002), The effect of using time-averaged winds on regional air-sea $\mathrm{CO}_{2}$ fluxes, in Gas Transfer at Water Surfaces, Geophysical Monograph 127, 351-356, AGU, Washington, DC.

Yamamoto-Kawai, M., F. A. McLaughlin, E. C. Carmack, S. Nishino, K. Shimada, and N. Kurita (2009a), Surface freshening of the Canada Basin, 2003-2007: River runoff versus sea ice meltwater, J. Geophys. Res., 114, C00A05, doi:10.1029/2008JC005000.

Yamamoto-Kawai, M., F. A. McLaughlin, E. C. Carmack, S. Nishino, and K. Shimada (2009b), Aragonite undersaturation in the Arctic Ocean: Effects of ocean acidification and sea ice melt, Science, 326(5956), doi:10.1126/science.1174190. 